\title{
Effect of Nasopharyngeal Irrigation on Early Eustachian Tube Functions in Patients Undergoing Adenoidectomy: A Clinical Prospective Study
}

\section{Adenoidektomi Sırasındaki Nazofaringeal İrigasyon Yönteminin Erken Dönemde Östaki Tüp Fonksiyonlarına Etkisi: Prospektif Çalışma}

\author{
(D) Şahin Öğreden, \\ (D) Cemal Özyılmaz, (D) Mehmet Faruk Oktay \\ Abdurrahman Buğra Cengiz, (1) Alper Tabaru,
}

University of Health Sciences, İstanbul Bağcllar Training and Research Hospital, Clinic of Otolaryngology, İstanbul, Turkey

Abstract

Objective: The hypertrophic adenoid tissue can cause to eustachian tube dysfunction by mechanical or inflammatory effect both of which block the nasopharyngeal ostium of the eustachian tube. Adenoidectomy, with or without tonsillectomy, is the most common surgical procedure in children. In this study, we aimed to investigate whether nasopharyngeal irrigation for hemorrhage control in adenoidectomy patients has an effect on eustachian tube functions.

Method: Patients who underwentadenoidectomy for adenoid hypertrophy evaluated on both the preoperatively and on the postoperative first day by otomicroscopic examination and with tympanometry for eustachian tube functions. Patients were divided into two groups according to nasopharyngeal irrigation type after surgery. Group 1 was the transnasal pressure irrigation group; group 2 was transoral passive irrigation group. Tympanometry was used to measure pressure, volumetric, and compliance values to compare pre- and postoperative values.

Results: 40 patients were included in the study. There was no significant difference between the age and sex distributions of the patients. Volume and compliance values between the groups were similar before and after the surgery. The mean pressure values of the tympanometry parameters were highly significantly different for the right ear and moderately different for the left ear in group 1; were significantly different for the right ear and highly significantly different for the left ear in group 2. Postoperative
Öz

\begin{abstract}
Amaç: Adenoid dokunun hipertrofisi, mekanik veya enflamatuvar süreçlerden dolayı östaki tüpünün nazofaringeal ağzını obstrükte ederek östaki disfonksiyonuna yol açmaktadır. Adenoidektomi, tonsillektomi ile birlikte çocuklarda yapılan en sık cerrahi prosedürdür. Bu çalışmada adenoidektomi yapılan hastalarda kanama kontrolü için yapılan nazofarenks irrigasyonunun östaki tüp fonksiyonlarına etkisinin olup olmadığını araştırmayı amaçladık.
\end{abstract}

Yöntem: Adenoid hipertrofisi nedeniyle opere edilen hastaların ameliyat öncesi ve ameliyat sonrası birinci gün otomikroskopik muayene ve timpanometri ile östaki tüp fonksiyonları değerlendirildi. Hastalar ameliyat sonrası nazofarenks irrigasyonuna göre iki gruba ayrıldı. Grup 1 hastalara transnazal basınçlı irrigasyon, grup 2 hastalara transoral pasif irrigasyon yapıldı. Timpanometri ile basınç, volüm, kompliyans değerleri ölçülerek ameliyat öncesi ve sonrası değerler karşılaştıııldı.

Bulgular: Çalışmaya 40 hasta dahil edildi. Hastaların yaş ve cinsiyet dağılımları arasında anlamlı bir fark bulunmadı. Gruplar arasında volüm ve kompliyans değerleri ameliyat öncesi ve sonrasında benzer bulundu. Timpanometri parametrelerinden basınç ortalama değerleri ameliyat öncesi-sonrası için grup 1'de sağ kulak için çok ileri düzeyde anlamlı olarak farklı ve sol kulak için sınırda anlamlı farklı iken, grup 2'de sağ kulak için ileri düzeyde anlamlı olarak farklı ve sol kulak için çok ileri düzeyde anlamlı olarak farklı idi. Ameliyat sonrası timpanometri tipleri grup 1'de

Address for Correspondence: Abdurrahman Buğra Cengiz, University of Health Sciences, İstanbul Bağcılar Training and Research Hospital, Clinic of Otolaryngology, İstanbul, Turkey

E-mail: drcengiz@gmail.com ORCID ID: orcid.org/0000-0003-3942-6765 Received: 23.01.2019 Accepted: 3.02.2019

Cite this article as: Öğreden Ş, Tansuker HD, Cengiz AB, Tabaru A, Özyılmaz C, Oktay MF. Effect of nasopharyngeal irrigation on early eustachian tube functions in patients undergoing adenoidectomy: a clinical prospective study. Bagcilar Med Bull 2019;4(1):16-20.

${ }^{\odot}$ Copyright 2019 by the Health Sciences University, Bagcilar Training and Research Hospital Bagcilar Medical Bulletin published by Galenos Publishing House. 


\section{Abstract}

tympanometry types were seen as bilateral type $\mathrm{C}$ in 7 patients, as right side type $C$ in 4 patients, as bilateral type $B$ in 2 patients, as left side type $C$ in 4 patients in group 1. However, in group 2, right side type B, left side type $B$ and bilateral type $C$ tympanogram were observed in 1 patient, 2 patients and 12 patients, respectively.

Conclusion: In this study, we observed that the nasopharyngeal irrigation to control bleeding after adenoidectomy had adverse effect on the eustachian tube functions but larger series of studies are needed to confirm this.

Keywords: Nasopharyngeal irrigation, adenoidectomy, tympanometry

\section{Öz}

7 hastada bilateral tip C, 4 hastada sağ tip C, 2 hastada bilateral tip B, 4 hastada sol tip $C$ görüldü. Grup 2'de ameliyat sonrası 1 hastada sağ tip $B$, 2 hastada sol tip B, 12 hastada bilateral tip C timpanogram izlendi.

Sonuç: Bu çalışmada adenoidektomi sonrası kanama kontrolü için yapılan nazofarenks irrigasyonunun östaki tüp fonksiyonlarına etkisinin olumsuz yönde olduğunu gördük ancak bunun doğrulanması için daha geniş serili çalışmalara intiyaç vardır.

Anahtar kelimeler: Adenoidektomi, nazofarenks irrigasyonu, timpanometri

\section{Introduction}

Eustachian tube dysfunction results in all acute and chronic otologic pathologies to begin. Blustone ve Doyle defined the functions of the eustachian tube as ventilation, drainage and protection of the middle ear. Any disruption of these functions initiates middle ear pathologies (1). Clinical audiometry and tympanometry can be used for screening and diagnosis. However, tympanometry is the gold standard for assessing middle ear pressure, volume and tympanic membrane compliance. Treatment may vary depending on the duration and severity of the disease. Adenoid tissue was first described by Meyer in 1868 as a lymphoid tissue that is part of the Waldayer ring. Adenoid hypertrophy obstructs the upper respiratory tracts and causes complaints such as chronic nasal obstruction, mouth open sleep, snoring and recurrent sinusitis (2).

Traditional adenoidectomy using curette was first described in 1885 (3). Traditional adenoidectomy is usually performed using curette. Adenoidectomy usually is not associated with significant bleeding. In this technique hemostasis is achieved by pressure using postnasal packing and/or irrigation with saline solutions (4). Mathiasen et al. (5) demonstrated the safety and efficacy of a novel hemostatic sealant in children undergoing adenoidectomy. The nasopharynx is generally irrigated with saline after adenoidectomy for removal of blood and clots (4). This can be performed by two ways; by transnasal pressure irrigation, and by transoral passive irrigation. However it has been speculated that the eustachian tube function could be affected by the irrigation process.

In this study, we aimed to investigate the effect of nasopharyngeal irrigation methods for hemostasis on eustachian tube function in patients undergoing adenoidectomy and to eliminate this defect in the literature since there has been no studies on this subject so far.

\section{Material and Methods}

The study is performed in İstanbul Bağcllar Training and Research Hospital and the study protocol was carried out in accordance with the principles of the European Ethical Commetee, and an approval from ethical committee in the same centre was obtained before initiation of the study (No: 2019.01.1.01.121.r1.001). Preoperative otomicroscopic examination and tympanometrywere performed to evaluate the eustachian tube functions indirectly. Patients with tympanic membrane adhesions, retraction or perforations; with congenital deformities such as cleft palate lips, with history of previous ear surgery, and tympanometry findings different from type A were excluded from the study. Under general anesthesia and supine position, adenoidectomy was performed by traditional curettage method in all patients. All of the operations were performed by the same experienced surgeon. Postoperative bleeding control was achieved with pressure and electro-cautery. The patients were divided into two groups randomly. In the first group, nasopharynx irrigation was performed transnasally by closing one of the nostrils with approximately $500 \mathrm{cc}$ physiological saline at the end of the operation. The patients in the second group were filled with saline orally and then nasopharynx irrigation was performed by aspiration. Patients in both groups were assessed by otomicroscopic examination and tympanometry on postoperative day 1. Tympanometry was performed again on the $7^{\text {th }}$ day of those who were not Type A.

\section{Statistical Analysis}

The minimum number of subjects required in each group was found to be 13 in order to make a significant difference 
of 97.00 between the two groups. Type I Error=0.05, power of test (POWER) 0.80 Statistical analyzes were performed with the program MedCalc (MedCalc Software, Broekstraat, Mariakerke, Belgium). Normal distribution of continuous variables was investigated by Kolmogorov-Smirnov test. Gaussian distributions were shown as mean \pm SD. The Student's t-test was used to compare the average values between the groups. The paired samples t-test was used in the comparison of the groups' average before and after surgery. Statistical significance was evaluated at the level of $\mathrm{p}<0.05$ (two-tailed).

\section{Results}

40 patients were included in the study. Fifteen patients (37.5\%) were female and 25 patients (62.5\%) were male. Age of the patients ranged from 1 to 15 years and the mean age was 6.87 years. Mean age of the patients was 6.8 in transnasal irrigation group (group 1) with 13 males and 7 females; and that was 6.9 in transoral irrigation group (group 2) with 12 males and 8 females (Table 1).

\begin{tabular}{llll} 
Table 1: Demografic features of the patients & \\
& $\begin{array}{l}\text { Transnasal } \\
\text { pressure } \\
\text { irrigation, } \\
\text { group 1 }(\mathbf{n}=\mathbf{2 0})\end{array}$ & $\begin{array}{l}\text { Transoral } \\
\text { passive } \\
\text { irrigation, } \\
\text { group 2 }(\mathbf{n}=20)\end{array}$ & $\mathbf{p}$ \\
Age (year) & $6.8 \pm 2.9$ & $6.9 \pm 3.0$ & $=0.915$ \\
Male/Female (N/N) & $13 / 7$ & $12 / 8$ & $=0.744$ \\
\hline
\end{tabular}

There was no significant difference between the age and sex distributions of the patients. Volume and compliance values between the groups were similar before and after the surgery.

The mean pressure values of the tympanometry parameters were highly significantly different for the right ear and moderately different for the left ear in group 1; were significantly different from the pressure parameters comparing group 2 (Table 2) The pressure levels in group. Postoperative tympanometry types were seen as bilateral type $\mathrm{C}$ in 7 patients, as right side type $\mathrm{C}$ in 4 patients, as bilateral type B in 2 patients, as left side type $\mathrm{C}$ in 4 patients in Group 1. However, in group 2, right side type B, left side type $B$ and bilateral type $C$ tympanogram were observed in 1 patient, 2 patients and 12 patients, respectively.

\section{Discussion}

The eustachian tube extends between the middle ear and the nasopharyngeal cavity and provides ventilation, drainage and protection of the middle ear. The most important function of the eustachian tube is the balance between the middle ear and atmospheric pressure (6). Adenoid tissue is localized in the lymphoepithelial tissue of the nasopharynx. The enlarged adenoid tissue results in nasopharyngeal obstruction. Adenoid hypertrophy is diagnosed by endoscopic nasopharyngoscopy and cephalometric radiography (7). Adenoidectomy is a

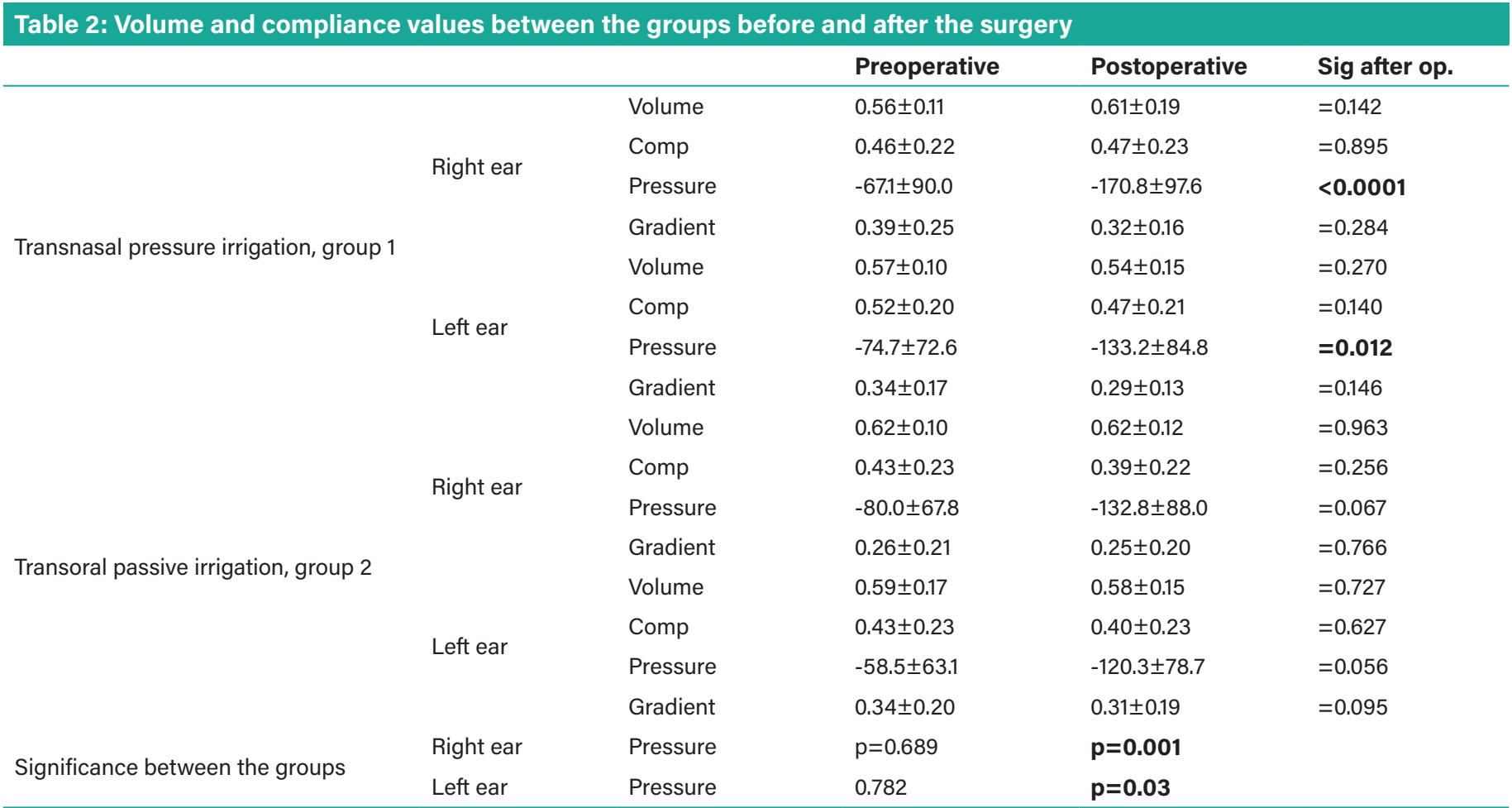


frequently performed surgical procedure. In 1885, Wilhem Mayer first described adenoidectomy technique by curettage method that is still current today (3).

Ünlü et al. (8) reported 64 patients to have bilateral traumatic tube dysfunction, and 10 patients to have unilateral eustachian tube dysfunction preoperatively in a study of adenoidectomy and tonsillectomy performed 64 patients. In the tympanometric examination they performed on the seventh day postoperatively, they found that 2 patients had bilateral traumatic tube dysfunction. In our study, we found that all of the tympanometric examinations we performed on the seventh postoperative day were normal. Thompson and Crowthe reported at least one ear to have type C tympanogram in 34 of 63 patients with septoplasty (9). In our study we observed that 27 of 40 patients with adenoidectomy had type C tympanograms. Montaño-Velázque et al. (10) reported significant tympanometric abnormalities and decreased middle ear pressure in 20 patients aged between 4 to 9 years who underwent adenotonsillectomy. They thought that this abnormality was due to the deterioration of the coordination of the eustachian tube and nasopharyngeal muscles. In our study we observed that the middle ear pressure was falling and that resulted in type $\mathrm{C}$ tympanogram. Şereflican et al. (11) reported that edema induced eustachian tube dysfunction developed in 30 patients performed anterior nasal packing comparing to and improvement of eustachian tube function after took packing off postoperatively. Yllmaz et al. (12) reported that middle ear pressures continued to decrease in the nasal packing group rather than silicone nasal septal splint group after one week. In a study of 25 patients with adenotonsillectomy, type c tympanogram was reported in $74 \%$ on the first postoperative day (13). Hone et al. (14) reported that $39 \%$ of the patients had eustachian tube disfunction by tympanometric examination on first day after adenotonsillectomy. In our study, similar to these two studies, we found mean pressure values of the tympanometry parameters (type C tympanogram) were highly significantly different for the right ear and moderately different for the left ear in the transnasal pressure irrigation group; those were significantly different for the right ear and highly significantly different for the left ear in the transoral passive irrigation group.

\section{Conclusion}

In this study, we observed that the nasopharyngeal irrigation to control bleeding after adenoidectomy had adverse effect on the eustachian tube functions but wider series of studies are needed to confirm this effect.

\section{Ethics}

Ethics Committee Approval: The study is performed in İstanbul Bağcllar Training and Research Hospital and the study protocol was carried out in accordance with the principles of the European Ethical Commetee, and an approval from ethical committee in the same centre was obtained before initiation of the study (no: 2019.01.1.01.121.r1.001).

Informed Consent: It was obtained from all the patients parents.

Peer-review: Externally peer-reviewed.

\section{Authorship Contributions}

Surgical and Medical Practices: Ş.Ö., A.T., C.Ö., Concept: Ş.Ö., H.D.T., A.B.C., M.F.O., Design: Ş.Ö., H.D.T., A.B.C., Data Collection or Processing: A.T., C.Ö., A.B.C., Analysis or Interpretation: Ş.Ö., H.D.T., A.B.C., M.F.O., Literature Search: Ş.Ö., H.D.T., A.B.C., Writing: Ş.Ö., A.B.C.

Conflict of Interest: No conflict of interest was declared by the authors.

Financial Disclosure: The authors declared that this study received no financial support.

\section{References}

1. Tysome JR, Sudhoff H. The Role of the Eustachian Tube in Middle Ear Disease. Adv Otorhinolaryngol 2018;81:146-152.

2. Mikals SJ, Brigger MT. Adenoidectomy as an adjuvant to primary tympanostomy tube placement: a systematic review and metaanalysis. JAMA Otolaryngol Head Neck Surg 2014;140:95-101.

3. Thornval A. Wilhelm Meyer and the adenoids. Arch Otolaryngol Head Neck Surg 1969;90:383-386.

4. Ozmen S, Ozmen OA. Hot saline irrigation for control of intraoperative bleeding in adenoidectomy: a randomized controlled trial. Otolaryngol Head Neck Surg 2010;142:893-897.

5. Mathiasen RA, Cruz RM. Prospective, randomized, controlled clinical trial of a novel matrix hemostatic sealant in children undergoing adenoidectomy. Otolaryngol Head Neck Surg 2004;131:601.

6. Hong J, Chen K, Lyu H, Yin D, Yang L, Zhang T, Dai P. Age-related changes in the morphological relationship between the supratubal recess and the Eustachian tube. Auris Nasus Larynx 2018;45:88-95.

7. Paradise JL, Bernard BS, Colborn DK, Janosky JE. Assessment of adenoidal obstruction in children: clinical signs versus roentgenographic findings. Pediatrics 1998;101:979-986.

8. Unlu I, Unlu EN, Kesici GG, Guclu E, Yaman H, Ilhan E, Ulucanl S, Karadeniz D, Memis M. Evaluation of middle ear pressure in the early period after adenoidectomy in children with adenoid hypertrophy without otitis media with effusion. Am J Otolaryngol 2015;36:377-381.

9. Thompson AC, Crowther JA. Effect of nasal packing on eustachian tube function. J Laryngol Otol 1991;105:539-540. 
10. Montaño-Velázquez BB, Villanueva-Padrón LA, Conde-Vázquez E, Alvarez-Romero E, Romero-Asato JG, Jáuregui-Renaud K. The middle ear pressure does not change after adenotonsillectomy in children younger than 10 years old. Rev Invest Clin 2014;66:152156.

11. Şereflican M, Yurttaş V, Oral M, Yılmaz B, Dağlı M. Is Middle Ear Pressure Effected by Nasal Packings after Septoplasty? J Int Adv Otol 2015;11:63-65.

12. Yilmaz MS, Guven M, Buyukarslan DG, Kaymaz R, Erkorkmaz U. Do silicone nasal septal splints with integral airway reduce postoperative eustachian tube dysfunction? Otolaryngol Head Neck Surg. 2012;146:141-145.

13. Choi JH, Yoon HC, Kim TM, Choi J, Park IH, Kim TH, Lee HM, Lee SH, Lee SH. The immediate effect of adenotonsillectomy on Eustachian tube function in children. Int J Pediatr Otorhinolaryngol 2015;79:1444-1447.

14. Hone SW, Moodley S, Donnelly MJ, Fenton JE, Gormley PK, Walsh M. The effect of tonsillectomy on eustachian tube function. Clin Otolaryngol Allied Sci 1997;22:511-514. 